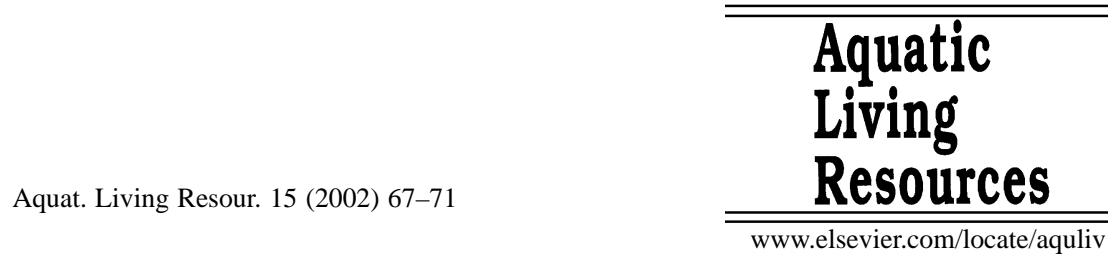

Note

\title{
Recent invasion of the Japanese oyster drill along the French Atlantic coast: identification of specific molecular markers that differentiate Japanese, Ocinebrellus inornatus, and European, Ocenebra erinacea, oyster drills
}

\author{
Pascale Garcia-Meunier ${ }^{\text {a }}$ *, Corine Martel a , Jacques Pigeot a, Guillemette Chevalier a, \\ Gérard Blanchard ${ }^{\mathrm{a}}$, Philippe Goulletquer ${ }^{\mathrm{b}}$, Stéphane Robert ${ }^{\mathrm{b}}$, Pierre-Guy Sauriau ${ }^{\mathrm{c}}$ \\ a Laboratoire de Biologie et Environnement Marins (LBEM), Université de la Rochelle, Avenue Michel Crépeau, 17042 La Rochelle cedex, France \\ ' IFREMER, Shellfish Aquaculture Research Laboratory (LCPC), Ronce-les-Bains, 17320 La Tremblade, France \\ ${ }^{\mathrm{c}}$ Centre de Recherche en Écologie Marine et Aquaculture (CREMA), UMR 10 CNRS-IFREMER, place du Séminaire, BP 5, 17137 L'Houmeau, France
}

Received 5 June 2001; accepted 30 October 2001

\begin{abstract}
The direct amplification of length polymorphism technique (DALP) has been used to distinguish species-specific banding patterns in two marine gastropod oyster drills Ocenebra erinacea (Linnaeus, 1758) and Ocinebrellus inornatus (Récluz, 1851). Ocenebra erinacea is the European oyster drill, common along all European coasts. Ocinebrellus inornatus, the Japanese oyster drill, was recorded in oyster growing areas of the Marennes-Oléron Bay (SW France) for the first time in 1995. This new biological invasion could lead to an increase, which must be evaluated, in the predation risk for cultivated species i.e. oysters and blue mussels, and for littoral fishing resources along the French Atlantic coasts. As a result, since specific identification of early life stages of both species (egg capsules and juveniles) was previously found to be both difficult and unsure using only morphological criteria, four Ocenebra erinacea and two Ocinebrellus inornatus specific molecular markers were identified and sequenced. These markers will facilitate the assessment of respective ecological impacts (reproductive patterns, abundance and spatial distribution of juveniles), resulting from the exotic species versus the native species and will allow us to analyse with certainty demographic profiles of the two oyster drill populations. (C) 2002 Ifremer/CNRS/Inra/Cemagref/Éditions scientifiques et médicales Elsevier SAS. All rights reserved.
\end{abstract}

Keywords: Molecular markers; Marine bioinvasions; Ocinebrellus inornatus; Ocenebra erinacea; French Atlantic coast

\section{Introduction}

Although they have existed for several centuries (Elton, 1958), biological invasions in marine environments have accelerated considerably over the past decades, mainly due to human-mediated dispersal mechanisms such as water ballast releases and ship fouling. The release of marine organisms for mariculture purposes (e.g. oyster and mussel industries) represents a significant vector of marine biological invasions (Carlton, 1992). Indeed, the intentional release

\footnotetext{
* Corresponding author.

E-mail address: pascale.garcia-meunier@univ-lr.fr (P. GarciaMeunier).
}

of species for aquaculture purposes is also known to be accompanied by the indirect introduction of associated vegetal and animal species (Gruet and Baudet, 1997). Moreover, the management of cultivated species, due to the movement of the allochtonous species (i.e., egg capsules, spat, juveniles, adults), which settle on transported materials between shellfish production areas, accelerates the spread of the invasion. These phenomena induce potential ecological, economic and social risks (Boudouresque, 1994; Goulletquer, 1998, Jousson et al., 1998).

Shellfish farming activities in France provide a recent example of such a process with the discovery of the mollusc gastropod Ocinebrellus inornatus (Récluz, 1851) in the Marennes-Oléron Bay along the Atlantic coast (de Montaudouin and Sauriau, 2000; Pigeot et al., 2000). This Japanese 
Table 1

Sequences of the primers used. The L-primers share the same 5'core sequence (the universal M13 sequencing primer) and permutations of 2,3 or 4 nucleotides have been added at the 3 ' end of the common sequence (bold sequences). The reverse primer (DALP-R) is also one of the M13 reverse primers.

\begin{tabular}{lll}
\hline Set of primers & L primer & H primer (DALP-R) \\
\hline DALP-221 & 5'-GTTTTCCCAGTCACGACGC-3' & 5'-TTTCACACAGGAAACAGCTATGAC-3' \\
DALP-231 & 5'-GTTTTCCCAGTCACGACAGC-3' & 5'-TTTCACACAGGAAACAGCTATGAC-3' \\
DALP-232 & 5'-GTTTTCCCAGTCACGACGAC-3' & 5'-TTTCACACAGGAAACAGCTATGAC-3' \\
DALP-233 & 5'-GTTTTCCCAGTCACGACACG-3' & 5'-TTTCACACAGGAAACAGCTATGAC-3' \\
DALP-235 & 5'-GTTTTCCCAGTCACGACCAC-3' & 5'-TTTCACACAGGAAACAGCTATGAC-3' \\
DALP-242 & 5'-GTTTTCCCAGTCACGACCTAG-3' & 5'-TTTCACACAGGAAACAGCTATGAC-3' \\
\hline
\end{tabular}

oyster drill, native to Asian Pacific coasts, had already been introduced along the North-western American coast from Japan during the 1920s. On the French coast, Ocinebrellus inornatus was recorded in the oyster beds of MarennesOléron Bay for the first time in 1995, and has regularly been observed since then. According to the observations of Pigeot et al. (2000), its ecological niche seems to be similar to that of the native oyster drill Ocenebra erinacea (Linnaeus, 1758) which, until now, has been one of the main intertidal predators able to inflict real damage on cultivated oysters (Deltreil and Marteil, 1976).

Therefore, it is of prime importance to test whether this recent invasion increases the risk of predation upon cultivated stocks (i.e., oysters Crassostrea gigas and Ostrea edulis, and mussels Mytilus edulis and Mytilus galloprovincialis along the French Atlantic coast) and more generally to assess its impact on the structure and the functioning of the invaded ecosystem. In the end, the aim of our project is to analyse the life history (demographic profiles and population dynamics) of the native and the non-native species, because they share the same niche and have potentially similar negative impacts, even though it is anticipated that the non-native species will have a stronger impact as reported for other alien predators e.g., Carcinus maenas (Grosholz and Ruiz, 1996). Indeed, the biology of these organisms is few described and hybridisation between Japanese and European drills has never been documented. However, our first investigations were severely limited by the difficulty to distinguish egg capsules and juveniles between both species, using only morphological criteria. Consequently, a complementary molecular approach seemed to be, in this case, particularly relevant to corroborate species determination.

In the present study, we have developed an original approach to take advantage of the molecular tools of population genetics, usually absent in this kind of investigation (Boudouresque et al., 1994; Farnham, 1997; Lee and Bell, 1999; Ricciardi and MacIsaac, 2000), in addition to the essential studies of taxonomy and ecology. We have thus identified specific nuclear markers for these two species Ocenebra erinacea and Ocinebrellus inornatus. These markers allowed species identification to be ascertained.

\section{Material and methods}

\subsection{Sampling}

Thirty adults from each species were randomly collected from three wild populations and then frozen at $-20^{\circ} \mathrm{C}$ until further processing. The three sampling sites (Fouras, Château d'Oléron, and Rivedoux) are distributed along the French Atlantic coast in the shellfish area of MarennesOléron which gather the main French sites for oyster seed collection on artificial collectors (Héral, 1989) that can be transferred to any other Atlantic and Mediterranean shellfish areas by professional shellfish operators. In comparison, Ocinebrellus inornatus from western North America (Washington State) and South Korea (Chinhae Bay near Pusan, $35^{\circ} 04^{\prime} \mathrm{N}, 128^{\circ} 50^{\prime} \mathrm{E}$ ) were tested too, in order to avoid fixed polymorphism at one location. Adult specimen were specifically determined by morphological criteria according to Abbott (1974) and Graham (1988) for Ocinebrellus inortatus and Ocenebra erinacea, respectively.

\subsection{DNA extractions}

DNA extractions were carried out using a modification of the Chelex method (Estoup et al., 1996). Less than $1 \mathrm{~mm}^{3}$ of each individual was introduced into $500 \mu \mathrm{l}$ of the following buffer: Chelex 5\% (Chelex 100 resin), $10 \mu \mathrm{L}$ proteinase $\mathrm{K}$ (Merck) $20 \mathrm{mg} \cdot \mathrm{ml}^{-1}$. Samples were incubated on a rotating shaker for 3 hours at $55^{\circ} \mathrm{C}$, followed by a 20-minute incubation at $100^{\circ} \mathrm{C}$. Samples were then vortexed and centrifuged for 5 minutes at $5200 \mathrm{~g}$.

\subsection{Genomic fingerprinting}

Each sample was genetically characterised by genome random amplification. We performed a DNA fingerprinting technique called DALP (Direct Amplification of Length Polymorphisms) to compare the two species Ocenebra erinacea and Ocinebrellus inornatus. This technique uses an arbitrarily primed Polymerase Chain Reaction (AP-PCR) to produce genomic fingerprints and to facilitate sequencing of DNA polymorphisms in virtually any species (Desmarais et al., 1998). It combines the advantages of a high resolution 


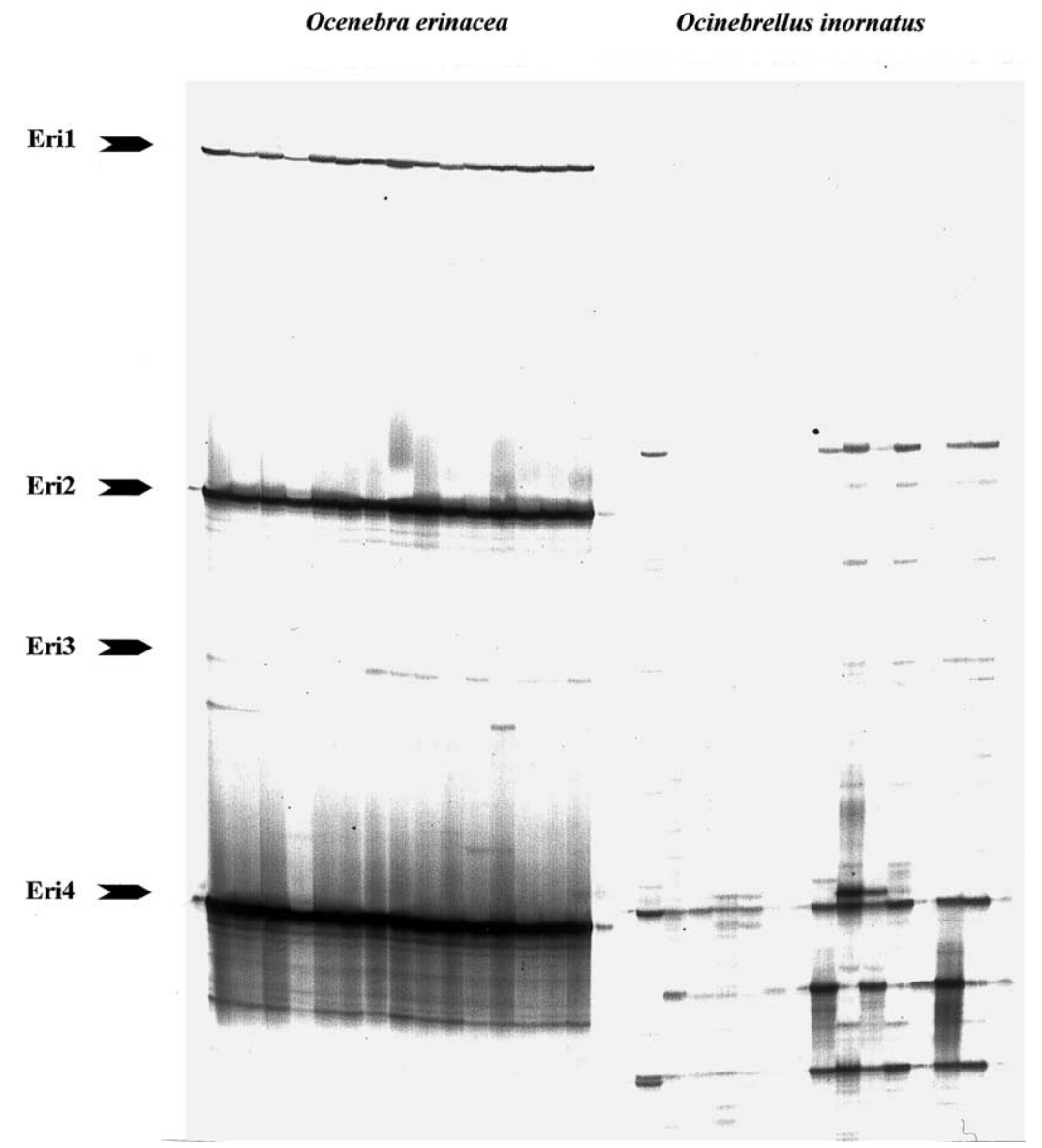

Fig. 1. Distinctive fingerprint with random primer DALP-231. The arrows show the four molecular primers specific for Ocenebra erinacea.

fingerprint technique and the possibility of characterising the polymorphisms with designation of locus-specific primers. Six sets of random primers were tested (Table 1).

PCR reactions were carried out in an MJ Research ${ }^{\mathrm{TM}}$ DNA Thermal Cycler with a heated lid. Each reaction was performed with a combination of one of the selective primers and the reverse primer DALP-R that was previously labelled with ATP ${ }^{33} \mathrm{P}$. The amplification was allowed after adding the following reagents: $2 \mu \mathrm{L}$ of DNA template, 5 pmol of each primer, $1.8 \mathrm{~mm} \mathrm{mgCl}_{2}, 100 \mu \mathrm{M}$ nucleotides (dNTPs) and $0.5 \mathrm{U}$ of Taq polymerase Goldstar (Eurogentec) in a $20 \mu \mathrm{L}$ reaction volume. The cycling parameters were 30 cycles of denaturation at $91{ }^{\circ} \mathrm{C}(30 \mathrm{~s})$, annealing at $50{ }^{\circ} \mathrm{C}(30 \mathrm{~s})$ and extension at $72{ }^{\circ} \mathrm{C}(30 \mathrm{~s})$. PCR results were resolved after electrophoresis on denaturing sequencing gels (6\% acrylamide) prepared with high quality acrylamide solution (acrylamide/bisacrylamide 29:1; Biorad) and run on a $50 \mathrm{~cm}$ long apparatus (Biorad).

\subsection{Specific markers}

After electrophoresis, drying and autoradiographing, four bands specific of Ocenebra erinacea (Fig. 1) and two bands specific of Ocinebrellus inornatus were extracted from the gel. The autoradiogram was precisely superimposed on the dried gel and the gel slice was cut through the film. Then, the Whatman paper with the acrylamide piece was directly immersed and re-amplified with the couple of primers in $20 \mu \mathrm{L}$ PCR mixture at the same analytical conditions as previously described. The re-amplified products were sequenced in an automated sequencer (Applied Biosystems) and inside these sequenced fragments stemming from the specific bands, four couples of primers specific to Ocenebra erinacea (Eri1, Eri2, Eri3, Eri4) and two couples of primers specific to Ocinebrellus inornatus (Ino1, Ino2) were defined and synthetized.

\subsection{Molecular identification of both species}

A molecular test, based on PCR amplification with to two sets of primers (specific to each species) allow the identification of individuals through acceptance or exclusion.

PCR reactions were carried out in an MJ Research ${ }^{\mathrm{TM}}$ DNA Thermal Cycler with a heated lid. Each reaction was performed with a combination of 2 sets of primers (specific to each species: Eri1, Eri2, Eri3, and Eri4 respectively associated with Ino1 or Ino2) and the amplification was allowed after adding the following reagents: $2 \mu \mathrm{L}$ of DNA template, $5 \mathrm{pmol}$ of each primer, $1.8 \mathrm{~mm} \mathrm{mgCl}_{2}, 30 \mu \mathrm{M}$ nucleotides (dNTPs) and $1 \mathrm{U}$ of Taq polymerase Goldstar 
Table 2

Specific primers defined.

\begin{tabular}{lll}
\hline Set of primers & L primer & H primer \\
\hline Eri1 & 5'-CTCACGGAAAATATCTTGGC-3' & 5'-AGCCTGATGCGATGGGATGC-3' \\
Eri2 & 5'-GTATGGATACCGAGATGAGC-3' & 5'-CCACAGGAAACAGCTATGAC-3' \\
Eri3 & 5'-ACGACTCTTTGAACGCCGCG-3' & 5'-TGACAAGACGAAGGGCCTGG-3' \\
Eri4 & 5'-GTATCAACAAATGACACGCG-3' & 5'-GACATGACAAAGAAGTCCTC-3' \\
Ino1 & 5'-CACTAATAAATGACCAG-3' & 5'-ACGTGTTGATTATGACG-3' \\
Ino2 & 5'-GAAGTGACAGATAGACTGCC-3' & 5'-GGTTTGTCAATGATGTGTAC-3' \\
\hline
\end{tabular}

(Eurogentec) in a $20 \mu \mathrm{L}$ reaction volume. The cycling parameters were 30 cycles of denaturation at $95^{\circ} \mathrm{C}(30 \mathrm{~s})$, annealing at $50{ }^{\circ} \mathrm{C}(30 \mathrm{~s})$ and extension at $72{ }^{\circ} \mathrm{C}(1 \mathrm{~min})$.

\section{Results and discussion}

\subsection{Interspecific polymorphism}

Only two couples of DALP primers revealed distinctive fingerprints for both species. The comparative profiles obtained with DALP-231/DALP-R simultaneously on the two species, clearly showed 4 molecular markers present only in Ocenebra erinacea adults, but absent in Ocinebrellus inornatus adults (Fig. 1). Those obtained with DALP235/DALP-R revealed 2 markers present only in Ocinebrellus inornatus adults. Sequencing these molecular markers allowed us to synthesize 4 couples of primers specific to Ocenebra erinacea (Eri1, Eri2, Eri3, Eri4) and 2 couples of primers specific to Ocinebrellus inornatus (Ino1, Ino2) (Table 2).

\subsection{Molecular identification of both species}

In order to perform future and reliable specific discrimination among egg capsules and juveniles of both species (to date difficult, unsure, and time-consuming because based on classical morphological identification), we set up a molecular test, whose main advantages are its simplicity and reliability. Its rationale is to couple two sets of primers (specific to each species) to allow the identification of individuals through acceptance or exclusion after PCR amplification and a simple agarose gel run.

Only two coupling systems were efficient: Eri2/Ino2 and Eri4/Ino2. Our results were optimum for a 1:1 ratio of the two sets of primers for system Eri2/Ino2 and system Eri4/Ino2. Under these conditions, our method was tested on 30 Ocenebra erinacea and Ocinebrellus inornatus adults as template, and previously identified morphologically without any ambiguity.

Using the Eri2/Ino2 coupling system, the PCR amplification revealed a 280 bp band due to the Eri2 primers, which is characteristic of Ocenebra erinacea (Fig. 2). Ocinebrellus inornatus adults only had the $170 \mathrm{bp}$ band due to the amplification with the Ino2 primers (Fig. 2). Similar results were obtained using the second coupling system, with a single 80-bp band (Eri4) for Ocenebra erinacea and a single 170-bp band (Ino2) for Ocinebrellus inornatus adults.

The good agreement between the molecular and morphological identifications of oyster drill adults allows this test to be extrapolated to egg capsules and juvenile stages, whose morphological identification is extremely difficult and unreliable. Therefore, it is now possible to analyse population dynamics and some fundamental reproductive features of the two species, such as number of egg capsules, size of capsule clusters, survival, and juveniles growth and spreading rates. This information is absolutely necessary to understand the ecological mechanisms underlying the invasion.

\section{Conclusion}

The present study confirms the potential of DALP markers species identification in marine gastropods. Indeed, we have identified nuclear specific markers for the European oyster drill, Ocenebra erinacea and the nonindigenous Japanese oyster drill, Ocinebrellus inornatus that have coexisted in the Marennes-Oléron Bay since 1995. Identification of specific nuclear markers for Ocenebra erinacea and the non-indigenous Ocinebrellus inornatus, provides baseline information that can be used as taxonomic diagnostic markers between the two species for an easy, fast and reliable specific identification at any life stages, including egg capsules and juvenile stages that are morphologically similar. Therefore, the markers will now facilitate the assessment of the ecological impacts (abundance, distribution of the introduced oyster drill) resulting from this exotic species, and will allow very reliable analyse of demographic

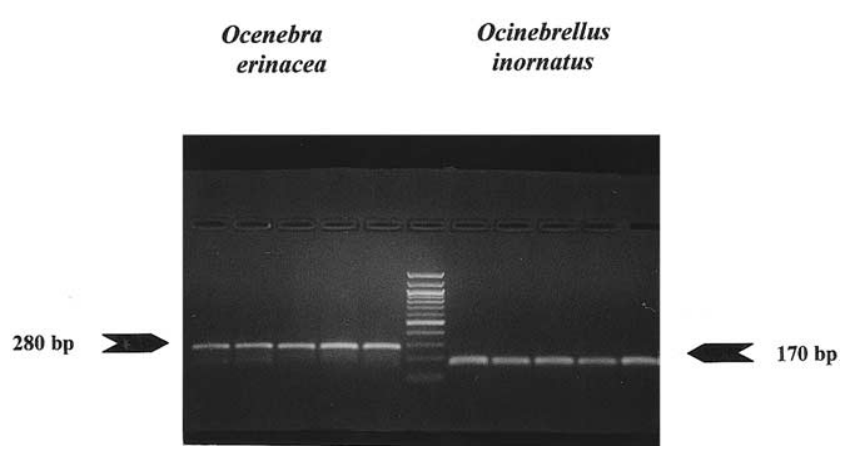

Fig. 2. Results of a PCR performed on five $O$. erinacea and five O. inornatus with the set of primers Eri2/Ino2. 
profiles of non indigenous species populations (vs. indigenous species populations).

\section{Acknowledgements}

Financial support for this work was provided by contracts from "Le Conseil Général de la Charente-Maritime" and "Le Ministère de l'Aménagement du Territoire et de l'Environnement". C.M get a Ph. D fellowship from "Le Ministère de l'Éducation Nationale, de la Recherche et de la Technologie". Thanks are due to Kang C.K. and Cheney D. for providing us with Ocinebrellus inornatus samples from South Korea and USA, respectively.

\section{References}

Abbott, R.T., 1974. American seashells. The marine mollusca of the Atlantic and Pacific coasts of North America. 2nd edition. Van Nostrand Reinhold Co., New York.

Boudouresque, C.F., 1994. Les espèces introduites dans les eaux côtières d'Europe et de Méditerranée: état de la question et conséquences. In: Boudouresque, C.F., Briand, F., Nolan, C (Eds.), Introduced species in European coastal waters. European Commission, Bruxelles, pp. 8-24.

Carlton, J.T., 1992. Introduced marine and estuarine molluscs of North America: an end-of-the-20th-century perspective. J. Shellfish Res. 11, 489-505.

Deltreil, J.-P., Marteil, L., 1976. Les ennemis de l'huître et de l'ostréiculture. Chapitre V. In: Marteil, L (Ed.), La conchyliculture française. 2e partie. Biologie de l'huître et de la moule. Rev. Trav. Inst. Pêches Marit. 40, 257-284.

Desmarais, E., Lanneluc, I., Lagnel, J., 1998. Direct amplification of length polymorphism (DALP) or how to get and characterize new genetic markers in many species. Nucleic Acids Res. 26, 6-10.

Elton, C.S., 1958. The ecology of invasions by animals and plants. Methuen Ed., London.

Estoup, A., Largiader, C.R., Perrot, E., Chourrout, D., 1996. Rapid one tube DNA extraction for reliable PCR detection of fish polymorphic markers and transgenes. Mol. Mar. Biol. Biotechnol. 5, 295-298.
Farnham, W.F., 1997. Espèces invasives sur les côtes de la Manche et de l'Atlantique. Dynamiques d'espèces marines invasives: application à l'expansion de Caulerpa taxifolia en Méditerranée. Tech. \& Doc Lavoisier, Paris, pp. 15-36.

Goulletquer, P., 1998. National report for France on introductions and transfers of marine organisms. ICES/WG.ITMO, Den Haag, The Netherlands, 24-27.03.98.

Graham, A., 1988. Molluscs: Prosobranchs and Pyramidellid Gastropods. Keys and notes for the identification of the species. Synopses of the British Fauna, New Series, 2 (2nd edition). In: Brill, E.J., Backhuys, W (Eds.), Leiden.

Grosholz, E.D., Ruiz, G.M., 1996. Predicting the impact of introduced species: lessons from the multiple invasions of the European green crab Carcinus maenas. Biol. Conserv. 78, 59-66.

Gruet, Y., Baudet, J., 1997. Les introductions d'espèces d'invertébrés marins. In: Dauvin, J.C (Ed.), Les biocénoses marines et littorales françaises des côtes Atlantique, Manche et mer du Nord: synthèse, menaces et perspectives. Laboratoire de Biologie des Invertébrés Marins et Malacologie - Service du Patrimoine Naturel / IEGB / MNHN, Paris. pp. 242-250.

Héral, M., 1989. Traditional oyster culture in France. Chapter 3. In: Barnabé, G (Ed.), Aquaculture, vol I. Tech. \& Doc., Lavoisier, Paris, pp. 342-387.

Jousson, O., Pawlowski, J., Zaninetti, L., Meinesz, A., Boudouresque, C.F., 1998. Molecular evidence for the aquarium origin of the green algea Caulerpa taxifolia introduced to the Mediterranean sea. Mar. Ecol. Prog. Ser. 172, 275-280.

Lee, C.E., Bell, M.A., 1999. Causes and consequences of recent freshwater invasions by saltwater animals. Trends Ecol. Evol. 14, 284-288.

Montaudouin de, X., Sauriau, P.-G., 2000. Contribution to a synopsis of marine species richness in the Pertuis Charentais Sea with new insights in soft-bottom macrofauna of the Marennes-Oléron Bay. Cah. Biol. Mar. 41, 181-222.

Pigeot, J., Miramand, P., Garcia-Meunier, P., Guyot, T., Séguignes, M., 2000. Présence d'un nouveau prédateur de l'huître creuse, Ocinebrellus inornatus (Récluz, 1851), dans le bassin conchylicole de MarennesOléron. C.R. Acad. Sci. Paris 323, 697-703.

Ricciardi, A., MacIsaac, H.J., 2000. Recent mass invasion of the North American Great Lakes by Ponto-Caspian species. Trends Ecol. Evol. 15, $62-65$. 